\title{
JNPH
}

Volume 6 No. 1 (April 2018)

(C) The Author(s) 2018

\section{FAKTOR-FAKTOR YANG BERHUBUNGAN DENGAN RESIKO JATUH PADA LANSIA DI BPPLU KOTA BENGKULU TAHUN 2017}

\author{
RELATED FACTORS WITH THE RISK OF FALLS LANSIA IN BPPLU \\ BENGKULU CITY IN 2017
}

\author{
RAVIKA RAMLIS \\ FIKES UNIVERSITAS DEHASEN BENGKULU, JL. MERAPI RAYA \\ NO. 43 KEBUN TEBENG BENGKULU \\ Email: ravikarramlis042gmail.com Hp.0853 67324044
}

\begin{abstract}
ABSTRAK
Insiden jatuh pada kelompok lansia dapat menyebabkan cedera pada jaringan lunak dan fraktur paha atau pergelangan tangan dan bahkan sampai mengakibatkan kematian. Selain itu, keadaan tersebut juga dapat menyebabkan berbagai masalah kesehatan yaitu: nyeri, ketidaknyamanan fisik, keterbatasan mobilisasi, dan proses penyembuhan yang lambat sehingga akan berdampak terhadap kondisilansia, dimana mereka akan mengalami masalah ketergantungan untuk melakukan aktivitas sehari-hari. Metode penelitian yang digunakan adalah desain penelitian deskriptif analitik. Penelitian ini mencoba mengumpulkan informasi mengenai factor-faktor yang berhubungan dengan resiko jatuh pada lansia meliputi factor intrinsic, ekstrinsik, dan situasional. Sampel dalam penelitian ini adalah seluruh lansia di BPPLU Kota Bengkulu yaitu sejumlah 60 orang. Tehnik pengambilan sampel dalam penelitian ini adalah total sampling. Hasil penelitian menunjukkan bahwa ada hubungan antara faktor intrinsik dengan risiko jatuh pada lansia di BPPLU Kota Bengkulu Tahun 2017. Ada hubungan antara faktor ekstrinsik dengan risiko jatuh pada lansia di BPPLU Kota Bengkulu Tahun 2017. Peneliti menyarankan kepada pihak BPPLU dapat menjadi landasan pelaksanaan program kegiatan bimbingan, pembinaan, dan konseling dalam upaya peningkatan pengetahuan tentang factor-faktor yang berhubungan dengan risiko jatuh pada lansia.
\end{abstract}

Kata kunci : Faktor, Intrinsik, Ekstrinsik, Risiko Jatuh

\begin{abstract}
The incidence of falls in the elderly group may cause injury to the soft tissues and fractures of the thigh or wrist and even result in death. In addition, the State also can cause a variety of health problems including: pain, physical discomfort, the limitations of mobilization, and the slow healing process so that it will have an impact towards kondisilansia, where they will experience the problem of addiction to perform daily activities. Research methods the research design used was descriptive analytic. The study tried to gather information on factor-related risk factors for falls in the elderly include factor intrinsic, extrinsic, and circumstantial. The sample in this study is the whole elderly in BPPLU city of Bengkulu, namely an amount of 60 people. The method of sampling in this research are the total sampling. The results showed that there is a relationship between the intrinsic risk factors for falls in the elderly in Bengkulu City Year 2017 BPPLU. There is a relationship between extrinsic factors with risk of falls in the elderly in
\end{abstract}


Bengkulu City Year 2017 BPPLU. Researchers suggest to the BPPLU can be a cornerstone of the implementation of the programme of activities, coaching, guidance and counseling in an attempt to increase knowledge about the factors factors that are associated with the risk of falls in the elderly.

Keywords : Intrinsic Factors, Risk Of Falls, The Extrinsic

\section{PENDAHULUAN}

Menurut World Health Organization (2014), proporsi penduduk di atas 60 tahun di dunia tahun 2000 sampai 2050 akan berlipat ganda dari sekitar $11 \%$ menjadi $22 \%$, atau secara absolut meningkat dari 605 juta menjadi 2 milyar lansia. Nazam (2013) melakukan survei tentang kejadian pasien jatuh di AS, dimana hasil survei tersebut menunjukkan 2,3-7\% per1000 lansia mengalami jatuh dari tempat tidur setiap hari dan 29-48\% lansia mengalami luka ringan dan 7,5\% dengan luka-luka serius. Kongres XII PERSI (2012) melaporkan bahwa angka kejadian pasien jatuh di Indonesia bulan Januari-September 2012 sebesar 14\%, hal ini menggambarkan presentasi angka pasien jatuh masuk ke dalam lima besar insiden medis selain medicine eror (Komariah, 2015).

Peningkatan jumlah lansia juga terjadi di negara Indonesia. Persentase penduduk lansia tahun 2011, 2012 dan 2013 telah mencapai di atas $7 \%$ dari keseluruhan penduduk, dengan spesifikasi 13,04\% berada di Yogyakarta, 10,4\% berada di Jawa Timur, 10,34\% berada di Jawa Tengah, dan 9,78\% berada di Bali (Susenas, 2014). Penduduk lansia terbesar di Yogyakarta berasal dari Kabupaten Sleman, yaitu berkisar 135.644 orang atau $12,95 \%$ dari jumlah penduduk Sleman (Pemkab Sleman, 2015).

\section{METODOLOGI PENELITIAN}

Penelitian ini yang digunakan adalah penelitian deskriptif analitik. Penelitian ini mencoba mengumpulkan informasi mengenai factor-faktor yang berhubungan dengan resiko jatuh pada lansia meliputi factor intrinsic, ekstrinsik, dan situasional. Penelitian ini merupakan penelitian non eksperimen karena tidak melakukan percobaan terhadap populasi dan sampel (Notoadmodjo, 2010).

\section{HASIL PENELITIAN}

\section{Analisis Univariat}

Analisis Univariat dilakukan untuk mendapatkan distribusi frekuensi faktorfaktor yang berhubungan dengan risiko jatuh pada lansia di BPPLU Bengkulu Tahun 2017.

a. Distribusi frekuensi faktor intrinsik di BPPLU Bengkulu Tahun 2017.

\section{Tabel 1. Distribusi frekuensi faktor intrinsik di BPPLU Bengkulu Tahun 2017}

\begin{tabular}{cccc}
\hline No & Faktor Intrinsik & Frekuensi & Persentase (\%) \\
\hline 1 & Tidak Terganggu & 26 & 43,3 \\
2 & Terganggu & 34 & 56,7 \\
\hline & Jumlah & 60 & 100 \\
\hline
\end{tabular}

Dari tabel 1 diatas menunjukkan bahwa sebagian besar dari responden $(56,7 \%)$ mengalami gangguan faktor intrinsik.

b. Distribusi frekuensi faktor intrinsik di BPPLU Bengkulu Tahun 2017.

Tabel 2. Distribusi frekuensi faktor ekstrinsik di BPPLU Bengkulu Tahun 2017

\begin{tabular}{cccc}
\hline No & Faktor Ekstrinsik & Frekuensi & Persentase (\%) \\
\hline 1 & Berisiko & 40 & 66,7 \\
2 & Tidak Berisiko & 20 & 33,3 \\
\hline & Jumlah & 60 & 100 \\
\hline
\end{tabular}

Dari tabel 2 diatas menunjukkan bahwa sebagian besar lansia $(66,7 \%)$ berisiko pada faktor ekstrinsik.

c. Distribusi frekuensi risiko jatuh di BPPLU 
Bengkulu Tahun 2017.

Tabel 3. Distribusi frekuensi risiko jatuh di BPPLU Bengkulu Tahun 2017

\begin{tabular}{cccc}
\hline No & Risiko Jatuh & Frekuensi & Persentase (\%) \\
\hline 1 & Tidak Berisiko & 15 & 25 \\
2 & Risiko Rendah Jatuh & 18 & 30 \\
3 & Risiko Tinggi Jatuh & 27 & 45 \\
\hline & Jumlah & 60 & 100 \\
\hline
\end{tabular}

Dari tabel 3 diatas menunjukkan bahwa hampir sebagian responden (45\%) berisiko tinggi jatuh.

\section{Analisis Bivariat}

Analisis ini dilakukan untuk mengetahui hubungan antara variabel Independent (Faktor Intrinsik) dengan variabel Dependent (Risiko Jatuh) di BPPLU Bengkulu.

a. Hubungan Faktor Intrinsik dengan Risiko Jatuh Pada Lansia di BPPLU Kota Bengkulu Tahun 2017

Tabel 4. Hubungan Faktor Intrinsik dengan Risiko Jatuh Pada Lansia di BPPLU Kota Bengkulu Tahun 2017

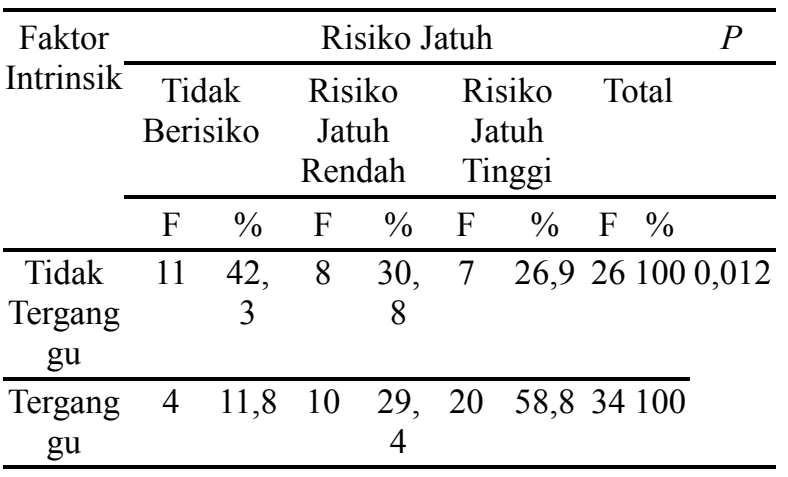

Dari tabel 4 diatas menunjukkan bahwa dari 34 orang yang mengalami gangguan faktor instrinsik sebagian besar responden $(58,8 \%)$ berisiko jatuh tinggi. Dari 26 orang yang tidak mengalami gangguan faktor intrinsik hampir sebagian besar $(26,9 \%)$ berisiko jatuh tinggi b. Hubungan Faktor Ekstrinsik dengan Risiko Jatuh Pada Lansia di BPPLU Kota Bengkulu Tahun 2017

Tabel 5. Hubungan Faktor Intrinsik dengan Risiko Jatuh Pada Lansia di BPPLU Kota Bengkulu Tahun 2017

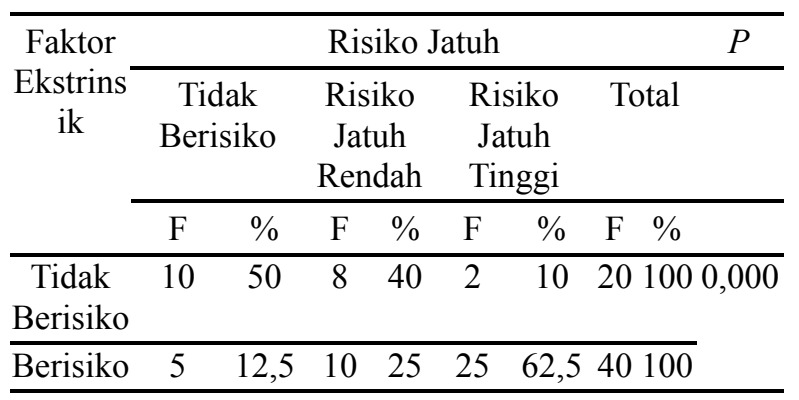

Dari tabel 5 diatas menunjukkan bahwa dari 40 orang yang mengalami risiko faktor ekstrinsik sebagian besarresponden (62,5\%) berisiko jatuh tinggi. Dari 20 orang yang tidak berisiko faktor ekstrinsik sebagian kecil responden $(10 \%)$ berisiko jatuh tinggi.

\section{PEMBAHASAN}

\section{Univariat}

\section{a. Faktor Intrinsik di BPPLU Kota Bengkulu Tahun 2017}

Hasil penelitian menunjukkan bahwa sebagian besar dari responden $(56,7 \%)$ mengalami gangguan faktor intrinsik. Hampir sebagian responden $(43,3 \%)$ tidak mengalmi gangguan faktor intrinsik.

Faktor intrinsik risiko jatuh pada lansia meliputi gangguan jantung, gangguan pada sistem anggota gerak, gangguan sistem saraf, gangguan penglihatan, dan gangguan pendengaran (Darmojo, 2004). Gangguan jantung pada lansia seperti hipertensi dimana tekanan darah sistolik sama atau lebih tinggi dari $140 \mathrm{mmHg}$ dan tekanan diastolik lebih tinggi dari $90 \mathrm{mmHg}$, yang terjadi karena menurunnya elastisitas arteri pada proses menua. Bila tidak ditangani, hipertensi dapat memicu terjadinya stroke, kerusakkan pembuluh darah (arteri osclerosis), 
serangan/gagal jantung sehingga dapat menyebabkan kejadian jatuh pada lansia (Darmojo, 2000).

\section{b. Faktor Ekstrinsik di BPPLU Kota Bengkulu Tahun 2017}

Hasil penelitian menunjukkan bahwa sebagian besar lansia $(66,7 \%)$ berisiko pada faktor ekstrinsik. Hampir sebagian responden $(33,3 \%)$ tidak berisiko faktor ekstrinsik.

Penggunaan alat bantu berjalan memang membantu meningkatkan keseimbangan,. Namun disii lain menyebabkan langkah yang terputus dan kecenderungan tubuh untuk membungkuk, terlebih jika alat bantu tidak menggunakan roda, karena itu penggunaan alat bantu berjalan ini haruslah direkomendasikan secara individual. Apabila kasus gangguan berjalan pada lansia tidak dapat ditangani dengan obat-obatan maupun pembedahan, maka salah satu penanganannya adalah dengn alat bantu berjalan seperti cane (tongkat), crutch (tongkat ketiak), dan walker. Ketika memilih alat bantu berjalan, anatomi tubuh dan sudut siku harus diperhatikan karena banyak dari mereka yang tidak dapat bantuan profesional dalam memilih alat bantu berjalan sehingga mengakibatkan bertambah buruknya gaya berjalan sehingga dapat memocu resiko jatuh (Darmojo, 2004).

\section{KESIMPULAN}

1. Sebagian besar responden mengalami gangguan faktor intrinsik pada lansia di BPPLU Kota Bengkulu Tahun 2017.

2. Sebagian besar lansia berisiko pada faktor ekstrinsik pada lansia di BPPLU Kota Bengkulu Tahun 2017.

3. Hampir sebagian responden berisiko tinggi jatuh pada lansia di BPPLU Kota Bengkulu Tahun 2017.

4. Ada hubungan antara faktor intrinsik dengan risiko jatuh pada lansia di BPPLU Kota Bengkulu Tahun 2017.

5. Ada hubungan antara faktor ekstrinsik dengan risiko jatuh pada lansia di BPPLU
Kota Bengkulu Tahun 2017.

\section{SARAN}

Diharapkan hasil penelitian ini dapat menjadi referensi atau masukan bagi perkembangan ilmu Keperawatan dan menambah kajian ilmu Keperawatan untuk mengetahui factor-faktor yang berhubungan dengan risiko jatuh pada lansia.

\section{DAFTAR PUSTAKA}

Aspiani. 2014. Buku Ajar Asuhan Keperawatan Gerontik. Jakarta: Trans Info Media

Barnedh, 2014. Penilaian Keseimbangan Menggunakan Skala

Keseimbangan.

http://www.uptodate.com, diakses tanggal: 08 Februari 2017

Cieayundacitra, 2010. Asuhan Keperawatan Pada Lansia $\begin{array}{r}\text { Dengan } \\ \text { Gangguan }\end{array}$
Penglihatan. http://blogspot.com, diperoleh pada tanggal 10 April 2017

Darmojo, R.B. \& Martono, H.H. (2004). Geriatri (Ilmu Kesehatan Usia Lanjut). Jakarta: Balai Penerbit FKUI

Darmojo, Boedhi, et al. Beberapa Masalah Penyakit Pada Usia Lanjut. Jakarta: Balai Penerbit FKUI, 2000.

Danar, Irawan Nurkuncoro. 2015. Pengaruh Latihan Keseimbangan Terhadap Risiko Jatuh Pada Lansia di Panti Sosial Tresna Werdha Yogyakarta Unit Budhi Luhur Kasongan Bantul [SKRIPSI]. STIKES Aisyiyah Yogyakarta

Erda. 2013. Faktor-faktor yang menyebabkan resiko jatuh dengan kejadian resiko jatuh pada lansia yang datang berobat ke Unit Pelayanan Primer Puskesmas Medan Johor, Medan. Universitas Sumatera Utara

Kemenkes.R.I. 2010. Pedoman Pembinaan Kesehatan Lanjut Usia Bagi Petugas Kesehatan. Jakarta: Direktorat Bina Kesehatan Komunitas

Komariah, S. 2015. Peran Perawat Dalam 
Menurunkan Insiden Keselamatan

Pasien Jatuh.[Online] available:

http://manajemen

rumahsakit.net/files/siti\%20komariah

$\% 20$ peran $\%$ KEP $\% 20$ dalam

\%20IKP.pdf [8 Februari 2017]

Kongres XII PERSI. 2012. Kejadian Jatuh Pada Lansia

Kurniawan. 2016. Hubungan Pengetahuan dan Perilaku Keluarga Dengan Risiko Jatuh Pada Lnsia di Desa Pondok Karanganon Klaten [Jurnal].

Universitas Muhammadiyah Yogyakarta

Kushariyadi. 2010. Asuhan Keperawatan

Pada Klien Lanjut Usia. Jakarta:

Salemba Medika 